\title{
Validation of computed tomography protocols for simulated mandibular lesions. A comparison study
}

\author{
Validação de protocolos de tomografia \\ computadorizada para lesões simuladas em \\ mandíbula. Estudo comparativo
}

\begin{abstract}
Andréia Perrella(a)
Maria Aparecida Borsatti ${ }^{(b)}$

Isabel Peixoto Tortamano ${ }^{(b)}$

Rodney Garcia Rocha ${ }^{(b)}$

Marcelo Gusmão Paraíso Cavalcanti ${ }^{(b)}$
\end{abstract}

(a) MSc Student; (b) Professors - Department of Stomatology, School of Dentistry, University of São Paulo.

\section{Corresponding author:}

Marcelo Gusmão Paraíso Cavalcanti

Faculdade de Odontologia da USP

Av. Professor Lineu Prestes, 2227, Cidade

Universitária, São Paulo - SP - Brazil

CEP: 05508-900

E-mail:mgpcaval@usp.br

\begin{abstract}
Computed tomography is the choice technique to assess oral and maxillofacial osseous lesions because it provides hard and soft tissues visualization in one examination without superimposition of surrounding structures. This examination offers a significant advance in maxillofacial lesions detection with an excellent anatomic resolution. The aim of this research was to evaluate the validity of two protocols, in axial sections, in simulated mandibular lesions. Two CT protocols were obtained in dry mandibles in which perforations were done simulating lesions. Two observers, previously calibrated, evaluated the images according to different parameters. The results indicated that the sensitivity and specificity in lesion detection were $100 \%$ for both protocols, but the detection of loci number of multilocular lesions and the location and detection of medullar invasion obtained reduced validity values, which were influenced by the acquisition protocol. We concluded that thinner axial slices and reconstructions were more effective in detecting early medullar invasion and loci number. Thicker protocols were not considered appropriate to detect multilocular lesions and early stages of medullar invasion.
\end{abstract}

Descriptors: Tomography, X-ray computed; Bone diseases; Mandible.

Resumo: A tomografia Computadorizada é a técnica de escolha no exame de lesões ósseas orais e maxilo-faciais porque proporciona a visualização de tecidos duros e moles em aquisição única e sem sobreposição de estruturas adjacentes. Este exame oferece um avanço significativo na detecção de lesões maxilo-faciais, com excelente resolução anatômica. O objetivo desta pesquisa foi avaliar a validade de dois protocolos, em secções axiais, em lesões simuladas de mandíbula. Dois protocolos de TC foram obtidos em mandíbulas secas em que foram feitas perfurações, simulando lesões. Dois observadores previamente calibrados avaliaram as imagens seguindo parâmetros diversos. Como resultados pudemos observar que a sensibilidade e a especificidade foram de $100 \%$ para detecção de lesões para ambos os protocolos, mas a detecção do número de lojas das lesões multiloculares e a localização e detecção de invasão medular obtiveram valores reduzidos em sua validade, o que foi influenciado pelo protocolo de aquisição. Concluiu-se que secções axiais e reconstruções mais finas foram mais efetivas na detecção de invasão medular precoce e de lojas tumorais. Protocolos mais espessos não foram considerados apropriados para a detecção de lesões multiloculares e estágios iniciais de invasão medular.

Descritores: Tomografia computadorizada por raios X; Doenças ósseas; Mandíbula. 


\section{Introduction}

Most of the developments in computed tomography $(\mathrm{CT})$ can be considered as attempts to provide better spatial resolution, shorter computer reconstruction, and faster acquisition times. ${ }^{14}$ The introduction of spiral CT in the early 1990s constituted a fundamental evolutionary step in the development and ongoing refinement of CT imaging techniques. ${ }^{5,9,11,14}$ The performance of helical CT requires several user-defined parameters. ${ }^{14}$

It has been demonstrated that CT provides better visualization of the jaws than other radiographic methods. ${ }^{1,6,7,15}$ The main reason for head and neck imaging is to evaluate the true extent of the disease to best determine surgical and therapeutic options. CT images provide information about cortical margins, extent of lesion, and involvement of surrounding structures. Knowledge of the cortical margin, of the teeth involved and of the position of the mandibular canal (neurovascular bundle) are important for surgical planning. Important anatomic variants must be pointed out so the surgeon can avoid potential intraoperative complications. ${ }^{2}$

Several authors have stated that the application of CT is useful in diagnosis and treatment planning of cystic lesions of the jaws. ${ }^{4,12,13,18,21}$ However, the CT scan operator needs to carefully select collimation, table increment, and reconstruction interval ${ }^{5}$ because manipulating the viewer controls (especially the window center) can have a significant influence on the apparent size and position of structures in the image., ${ }^{3,16}$ The orientation of the object to the scanning beam and the slice thickness protocol appear to have an impact on the accuracy and variability of the linear measurements taken in the $\mathrm{x}, \mathrm{y}, \mathrm{z}$ axes. ${ }^{8}$

In order to assess imaging interpretation and the variation of CT parameters, the aim of this work was to determine the accuracy (validity) of single slice CT in simulated mandible lesions according to different protocols of image acquisition.

\section{Material and Methods}

This research evaluated 15 dentate and edentulous dry mandibles in which lesions were produced involving only cortical or cortical and medullary cortex, using a high-speed hand piece with a 1012 dental round burr. The lesions were located in the buccal or lingual cortex of the mandibular body or of the symphysis region, and they presented different dimensions, shapes and loci numbers. The round burr used had a tip with $1 \mathrm{~mm}$ in diameter. In some cases, the burr just touched the cortical bone; in others, it was deepened into the medullary bone. Pendular movements were performed in order to produce larger simulated lesions, so the diameter of the simulated lesions ranged from $1 \mathrm{~mm}$ to $3 \mathrm{~mm}$, and their depth, from $0.5 \mathrm{~mm}$ to $3 \mathrm{~mm}$. Subsequently, all mandibles were imaged on a single slice helical CT (Hi Speed GE, Milwaukee, WI, USA) according to the following protocols:

- Protocol 1: One $\mathrm{mm}$ of slice thickness, $1 \mathrm{~mm}$ of interval of reconstruction for 1 second time, $80 \mathrm{kVp}, 130 \mathrm{~mA}, 512$ x 512 matrix, and a bone tissue filter.

The same specimens were then submitted to another protocol.

- Protocol 2: Three $\mathrm{mm}$ of slice thickness, $3 \mathrm{~mm}$ of interval of reconstruction, and the same scanning parameters as described above.

Scan angle and field of view were constant. The mandibles were scanned from their base to the condyle region by axial sections. The scanning plane was positioned parallel to the mandibular base. The Gantry angulation varied according to mandible base angulations. All procedures were conduced with the approval of the Ethical Committee, School of Dentistry, University of São Paulo (FOUSP).

All image data were sent in DICOM format (Digital Imaging Communication in Medicine) to a workstation (RA600 Workstation, GE Medical Systems, Milwaukee, USA). The data were recorded onto a CD-R and transferred to an independent computer (Pentium 4, 60 GB HD, 256 MB RAM). All images were displayed and analyzed using a commercially available software (eFilm version 1.5.3, Merge Healthcare, eFilm, Milwaukee, WI, USA).

The images were independently analysed by two previously calibrated observers in a randomized order, in two viewing sessions separated by an interval 
of, at least, 1 week. They were blinded to the acquisition method. The observers evaluated the absence or presence of bony destruction, their localization in each protocol, if there was medullary invasion, and the loci number of each lesion present. The statistical analysis was carried out with a validity test (sensitivity and specificity), using a commercially available statistical analysis package (MINITAB, Minitab Inc., State College, PA, USA).

\section{Results}

There was no statistically significant difference between inter- and intra-observer evaluations in both protocols. However, the results also showed more inter- and intra-observer variability in protocol 2. In both protocols, all lesions were detected.

Table 1 - Sensitivity and specificity in both protocols.

\begin{tabular}{l|c|c|c}
\hline & & Protocol 1 & Protocol 2 \\
\hline $\begin{array}{l}\text { Bone lesion } \\
\text { detection }\end{array}$ & Sensitivity & $100 \%$ & $100 \%$ \\
\cline { 2 - 4 } & Specificity & $100 \%$ & $100 \%$ \\
\hline \multirow{2}{*}{$\begin{array}{l}\text { Loci number } \\
\text { detection }\end{array}$} & Sensitivity & $75 \%$ & $64 \%$ \\
\cline { 2 - 4 } $\begin{array}{l}\text { Medullary invasion } \\
\text { detection }\end{array}$ & Specificity & $100 \%$ & $100 \%$ \\
\cline { 2 - 4 } & Sensitivity & $72 \%$ & $50 \%$ \\
\hline
\end{tabular}

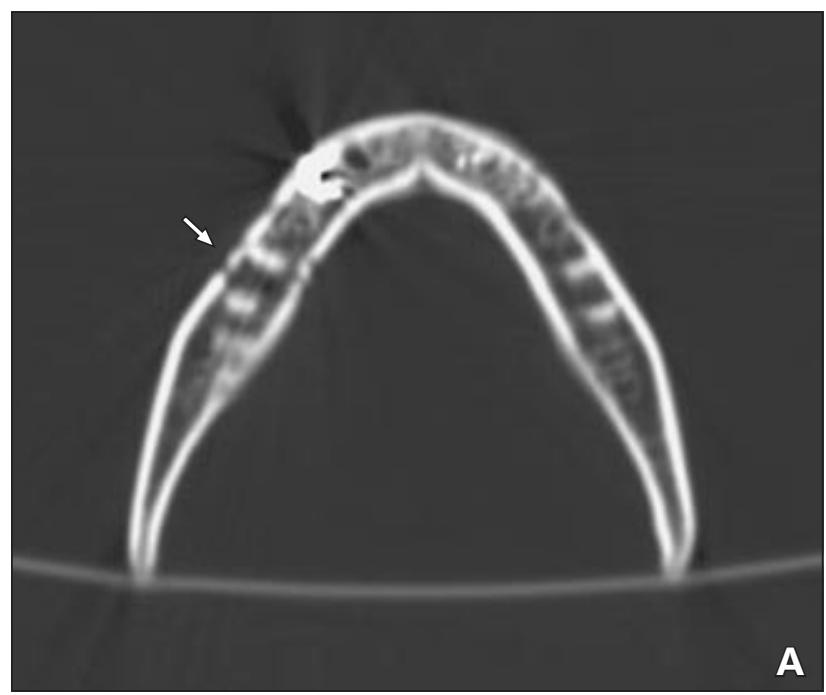

The CT sensitivity and specificity (accuracy) were thus $100 \%$. Sensitivity is correctly and unambiguously defined as the proportion of reference test positive (diseased) subjects who test positive with the screening test, and specificity is defined as the proportion of reference test negative (healthy) subjects who test negative with the screening test (Table 1). Regarding the detection of the loci number of multilocular simulated lesion, specificity was $100 \%$ in both protocols, but sensitivity was $75 \%$ in protocol 1 and $64 \%$ in protocol 2 (Table 1). As to medullary involvement, specificity was $99 \%$ and $97 \%$, and sensitivity was $72 \%$ and $50 \%$, respectively in protocols 1 and 2 (Table 1), (Figures 1A and 1B).

Using ANOVA, we compared the intra- and inter-observer assessments of the loci number of lesions, which achieved error values lower than $0.6 \%$ and did not differ significantly $(\mathrm{p}>0.05)$, as shown in Table 2.

Table 3 shows the average error values found using ANOVA for evaluation of the loci number. The difference between errors in both protocols was not significant $(\mathrm{p}=0.0760)$.

In the assessment of medullary invasion, we found significant differences between protocols 1 and $2(\mathrm{p}<0.01)$. The error value and standard deviation are presented in Table 3.

Figure 1 - Axial slices of the mandibular images in both protocols: $3 \mathrm{~mm} \times 3 \mathrm{~mm}(\mathbf{A}), 1 \mathrm{~mm} \times 1 \mathrm{~mm}(\mathbf{B})$. In figure $\mathbf{1 A}$, the arrow is showing destruction of the buccal cortex. In figure 1B, we can clearly see the multilocularity and medullary invasion of the same region presented in figure $\mathbf{1 A}$. 
Table 2 - Error, standard deviation (SD) and p values for intra- and inter-observer assessments in both protocols.

\begin{tabular}{l|c|c|c}
\hline & Error (\%) & SD (\%) & $p$ \\
\hline Intra-observer protocol 1 & 0.5746 & 2.2254 & 0.0943 \\
\hline Inter-observer protocol 1 & 0.5746 & 2.2254 & 0.3037 \\
\hline Intra-observer protocol 2 & 0.5578 & 2.1602 & 0.3037 \\
\hline Inter-observer protocol 2 & 0.5578 & 2.9910 & 0.0749 \\
\hline
\end{tabular}

Table 3 - Error and standard deviation (SD) values.

\begin{tabular}{l|c|c|c}
\hline & Protocol & Error (\%) & SD (\%) \\
\hline $\begin{array}{l}\text { Loci number detection in } \\
\text { protocols 1 and 2 }(p=0.0760)\end{array}$ & 1 & 0.9000 & 1.1453 \\
\cline { 2 - 4 } & 2 & 1.2500 & 1.4915 \\
\hline $\begin{array}{l}\text { Assessment of medullary } \\
\text { invasion in protocols 1 and 2 }\end{array}$ & 1 & 0.2500 & 0.4366 \\
\cline { 2 - 4 } & 2 & 0.5667 & 0.4996 \\
\hline
\end{tabular}

\section{Discussion}

Several imaging techniques, such as conventional radiographs, CT, PET (Positron emission tomography), and magnetic resonance imaging have been used for evaluation of malignant tumors in the region of the floor of mouth and of the tongue. Currently, CT is the technique preferred for diagnosis and treatment planning of bone lesions of the jaws, and it also allows differentiation between soft tissues. ${ }^{4,15}$

The present study obtained accuracy values of $100 \%$ in the detection of simulated bone lesions, thus agreeing with the studies by Lehrman et al. ${ }^{13}$ (1991), Huntley et al. ${ }^{10}$ (1996), van den Brekel et al. ${ }^{20}$ (1998). On the other hand, Shaha ${ }^{17}$ (1991), Tsue et al. ${ }^{19}$ (1994), Brown et al. ${ }^{5}$ (1994), found lower values of sensitivity and specificity in their studies, as they used larger slice thickness values in their acquisition protocols (over $4 \mathrm{~mm}$ ). The use of protocols with larger slice thickness values can lead to misinterpretation of the lesions. . $^{3,7,8,17,18}$

In the present research, the acquisition protocols were of $1 \mathrm{~mm} \times 1 \mathrm{~mm}$ and $3 \mathrm{~mm} \times 3 \mathrm{~mm}$, and an accuracy of $100 \%$ was obtained in the assessment of mandibular simulated lesions. However, Huntley et al. ${ }^{10}$ (1996) found a sensitivity of $62.5 \%$ with CT while analyzing bone invasion by squamous cell carcinoma using a protocol of $1.5 \mathrm{~mm}$ of slice thick- ness and $1.5 \mathrm{~mm}$ of interval of reconstruction. They observed all bone invasions in edentate patients and missed the invasion in dentate specimens. They concluded that CT appears to be useful in bony invasion in edentate specimens, but its use for dentate specimens is limited. The increasing tendency toward mandibular preservation demands more accurate methods of tumor localization..$^{10}$ In the present research, no difference was found between dentate and edentate specimens, as all lesions were detected in dentate and edentate mandibles. Nonetheless, future studies on adequate CT protocols are recommended in order to better detect mandibular lesions either in dentate or edentulous patients.

The present study disagrees with the study by Lehrman et al. (1991), who affirmed that CT can provide essential information concerning multilocularity of cystic lesions, ${ }^{13}$ as we found sensitivity values of $75 \%$ in protocol 1 and $64 \%$ in protocol 2 .

The smallest medullary invasions were difficult to visualize, as we found sensitivity and specificity values respectively of $72 \%$ and $99 \%$ in protocol 1 ( $1 \mathrm{~mm} \times 1 \mathrm{~mm}$ ), and $50 \%$ and $97 \%$ in protocol 2 ( $3 \mathrm{~mm} \times 3 \mathrm{~mm}$ ). Based on the obtained results, these lower values were influenced by the size of the simulated medullary invasion, which was smaller than the burr diameter (smaller than $1 \mathrm{~mm}$ ) and also smaller than the slice thickness and interval of reconstruction. This study corroborates that of Shaha (1991), who found that minimal invasion of the inner cortex was difficult to document on mandibular CT scan, and that it is essential that CT scans be performed with very narrow cuts. ${ }^{17}$

We believe that to accurately determine the size of lesions and to detect and evaluate lesions in a very early stage, thinner cuts obtained with CT multislice technology may improve the obtained results.

\section{Conclusions}

The validity of both protocols of CT imaging assessed in this study was established regarding the detection of the presence of bone lesions. The protocol with a thinner slice and a smaller reconstruction interval had detected more clearly smaller medullary invasions and lesion loci number. The thicker protocol was not considered appropriate to interpret 
multilocularity of lesions and early stages of medullary invasion.

\section{Acknowledgments}

We wish to thank the Department of Anatomy,

\section{References}

1. Abrahams JJ. Anatomy of the jaw revisited with a dental CT software program: pictorial essay. AJNR Am J Neuroradiol. 1993;14(6):979-90.

2. Alberico RA, Husain SH, Sirotkin I. Imaging in head and neck oncology. Surg Oncol Clin North Am. 2004;13(1):13-35.

3. Baxter BS, Sorenson JA. Factors affecting the measurement of size and CT number in computed tomography. Invest Radiol. 1981;16(4):337-41.

4. Bodner L, Bar-Ziv J, Kaffe I. CT of cystic jaw lesions. J Comput Assist Tomogr. 1994;18(1):22-6.

5. Brown JS, Griffith JF, Phelps PD, Browne RM. A comparison of different imaging modalities and direct inspection after periosteal stripping in predicting the invasion of the mandible by oral squamous cell carcinoma. Br J Oral Maxillofac Surg. 1994;32(6):347-59.

6. Cavalcanti MG, Ruprecht A, Vannier MW. 3D volume rendering using multislice CT for dental implants. Dentomaxillofac Radiol. 2002;31(4):218-23.

7. Cavalcanti MGP, Santos DT, Perrella A, Vannier MW. CTbased analysis of malignant tumor volume and localization. A preliminary study. Braz Oral Res. 2004;18(4):338-44.

8. Covino SW, Mitnick RJ, Shprintzen RJ, Cisneros GJ. The accuracy of measurements of three-dimensional computed tomography reconstructions. J Oral Maxillofac Surg. 1996;54(8):982-90.

9. Crawford CR, King KF. Computed tomography scanning with simultaneous patient translation. Med Phys. 1990;17(6):96782.

10. Huntley TA, Busmanis I, Desmond P, Wiesenfeld D. Mandibular invasion by squamous cell carcinoma: a computed tomographic and histological study. Br J Oral Maxillofac Surg. 1996;34(1):69-74.
Institute of Biomedical Sciences (ICB), University of São Paulo (USP). This study was supported by grants from FAPESP (Prof. Marcelo Cavalcanti, \#04/102764), São Paulo, SP, Brazil; and CAPES (Andréia Perrella), Brasília, DF, Brazil.

11. Kalender W, Seissler W, Klotz E, Vock P. Spiral volumetric CT with single-breath-hold technique, continuous transport, and continuous scanner rotation. Radiology. 1990;76(1):181-3.

12. Krennmair G, Lenglinger F. Imaging of mandibular cysts with a dental computed tomography software program. Int J Oral Maxillofac Surg. 1995;24(1 Pt 1):48-52.

13. Lehrman BJ, Mayer DP, Tidwell OF, Brooks ML. Computed tomography of odontogenic keratocysts. Comput Med Imaging Graph. 1991;15(5):365-8.

14. Mahesh M. Search for isotropic resolution in CT from conventional through multiple-row detector. Radiographics. 2002;22(4):949-62.

15. Millesi W, Prayer L, Helmer M, Gritzmann N. Diagnostic imaging of tumor invasion of the mandible. Int J Oral Maxillofac Surg. 1990;19(5):29428.

16. Ney DR, Fishman EK, Magid D, Robertson DD, Kawashima A. Three-dimensional volumetric display of CT data: effect of scan parameters upon image quality. J Computer Assisted Tomography. 1991;15(5):875-85.

17. Shaha AR. Preoperative evaluation of the mandible in patients with carcinoma of the floor of the mouth. Head Neck. 1991;13(5):398-402.

18. Toller MO, Sipahier M, Acikgoz A. CT display of multiple dentigerous cysts of the mandible: a case report. J Clin Pediatr Dent. 1995;19(2):135-7.

19. Tsue TT, McCulloch TM, Girod DA, Couper DJ, Weymuller EA Jr, Glenn MG. Predictors of carcinomatous invasion of the mandible. Head Neck. 1994;16(2):116-26.

20. van den Brekel MW, Runne RW, Smeele LE, Tiwari RM, Snow GB, Castelijns JA. Assessment of tumor invasion into the mandible: the value of different imaging techniques. Eur Radiol. 1998;8(9):1552-7.

21. Weber AL. Imaging of cysts and odontogenic tumors of the jaws. Radiol Clin North Am. 1993;31(1):101-20. 